\title{
THE POLITICS OF FREEDOM OF INFORMATION
}

HOW AND WHY GOVERNMENTS PASS LAWS THAT THREATEN THEIR POWER

COVERING $\infty D_{-10}^{\infty}$

\section{TOP}

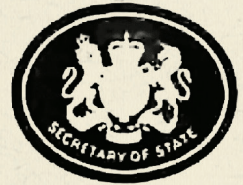

Lis Copy No 1 of 27 copies Page 1 of 2 pages

MINISTRY OF DEFENCE WHITEHALL LONDON SWIA $2 H B$

$$
\begin{aligned}
& \text { TELEPHONE O1-218 } 9000 \\
& \text { DIRECT DIALLING } 01-218 \ldots . . .211 / 3
\end{aligned}
$$

COVERING TOP SECRET UK EYES A

SECRET

MO $15 / 3$

PRIME MINISTER

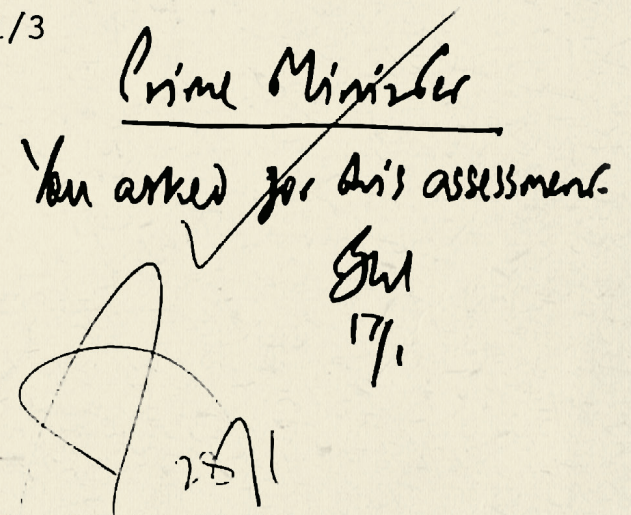

DEFENCE AGAINST THE SOVIET THREAT TO THE UNITED KINGDOM

\section{BEN WORTHY}




\section{The politics of freedom of information}

$\overline{\overline{ }}$

\section{MANCHESTER 1824}

Manchester University Press 
Ben Worthy - 9781526108517

Downloaded from manchesterhive.com at 04/26/2023 12:25:01PM via free access 


\title{
The politics of freedom of information
}

\author{
How and why governments \\ pass laws that threaten \\ their power
}

Ben Worthy

Manchester University Press 


\section{Copyright (C) Ben Worthy 2017}

The right of Ben Worthy to be identified as the author of this work has been asserted by him in accordance with the Copyright, Designs and Patents Act 1988.

Published by Manchester University Press

Altrincham Street, Manchester Mi 7JA

www.manchesteruniversitypress.co.uk

British Library Cataloguing-in-Publication Data

A catalogue record for this book is available from the British Library

Library of Congress Cataloging-in-Publication Data applied for

ISBN 978 o 719097676 hardback

First published 2017

The publisher has no responsibility for the persistence or accuracy of URLs for any external or third-party internet websites referred to in this book, and does not guarantee that any content on such websites is, or will remain, accurate or appropriate.

Typeset by

Servis Filmsetting Ltd, Stockport, Cheshire 